\title{
Biophysical and computational comparison on the binding affinity of important proteins of folic acid and its metal complexes
}

\section{Folik asit ve folik asitin metal kompleksleri ille bağlanma ilgisinin moleküler doking yoluyla, hesaplamalı ve biyofiziksel yönden karşılaştırılması}

\author{
Recep Akkaya
}

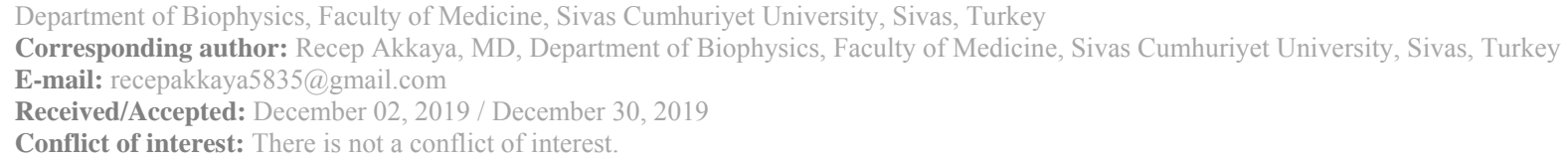

\section{SUMMARY}

It is important to note that folic acid is an important molecule in terms of human health. Folic acid that is one of the important molecules in human body plays an important role in the prevention of birth defects of the baby's brain (anencephaly) and spine (spina bifida). This molecule that is a form of vitamin B-9 can be easily dissolved in water media. Besides the molecule have important roles in nucleic acid production. Folic acid that is a complex type of vitamin B takes charge in the creating more red blood cells, preventing hearing loss, and preserving the brain health of infants. Because of the importance of folic acids and its derivatives, in this study, we analyzed the chemical reactivity of folic acid and its derivatives using DFT and Molecular Docking Programmes and investigated the power of the interactions with some well- known target proteins of the aforementioned molecules. Folic acid and its cadmium, copper and mercury complexes are performed in molecular docking studies for the activity against creatine kinase target protein in human brain.

Keywords: Biophysical analysis, folic acid, vitamin B-9, vitamin B-12, brain, biochemistry, metal complexs
ORCID IDs of the authors: R.A. 0000-0002-3477-7198

\section{ÖZET}

Folik asidin insan sağlığı açısından çok önemli bir moleküldür. İnsan vücudundaki önemli moleküllerden biri olan folik asit, bebeğin beyninin (anensefali) ve omurganın (spina bifida) doğum kusurlarının önlenmesinde önemli bir rol oynar. B-9 vitamini formu olan bu molekül su ortamında kolayca çözülebilir. Ayrıca molekülün nükleik asit üretiminde önemli rolleri vardır. Karmaşık bir B vitamini türü olan folik asit, daha fazla kırmızı kan hücresi yaratmada, işitme kaybını önlemede ve bebeklerin beyin sağlığını korumasından sorumludur. Folik asitlerin ve türevlerinin önemi nedeniyle, bu çalışmada folik asit ve türevlerinin DFT ve Moleküler Yerleştirme Programları kullanarak kimyasal reaktivitesini analiz ettik ve yukarıda adı geçen moleküllerin iyi bilinen bazı hedef proteinleri ile etkileşimlerinin gücünü araştırdık. Folik asit ve kadmiyum, bakır ve cıva kompleksleri, insan beynindeki kreatin kinaz hedef proteinine karşı moleküler doking çalışmaları gerçekleştirdik. 


\section{INTRODUCTION}

Folate is one of the well-known B vitamins. Folic acid ${ }^{1}$ converted to folate by the body is widely used in dietary supplementation. Folate is required to metabolize the amino acids required DNA, RNA and cell division ${ }^{2}$. For humans, this vitamin should be obtained from diet because human body cannot produce it. Recommended daily folate intake for adults is 400 micrograms. It is important to note that folate is used to treat the anemia caused by folate deficiency. In addition, folic acid is very important in terms of reducing the risk of neural tube defect in the baby. In many countries, to prevent the early birth, folic acid is added to the foods. In the literature, it was noted that excessive folic acid intake can trigger prostate cancer and It is well-known that big amounts of supplemental folic acid can hide vitamin B12 deficiency. Symptoms can be ordered as feeling tired, heart palpitations, shortness of breath, open sores on the tongue, and changes in the color of the skin or hair. It is important to note that Folic acid was found between 1931 and 1943 years. World health organization added ${ }^{3}$ folic acid to list of trusted drugs most needed. Folic means leaf in Latin.

Chemical reactivity theories are widely considered in the analysis of stability or reactivity of chemical compounds. Density Functional Theory ${ }^{4,5}$ that uses the electron density to describe the chemical reactivity is one of the popular theories used for this aim. The theory is quite important in terms of the understanding of the nature of chemical interactions and chemical reactions. At the present time, the scientific studies regarding the development of new DFT methods are very popular.

There are several chemical reactivity principles ${ }^{6,7}$ proposed about chemical reactivity descriptors like hardness, polarizability, electrophilicity in the literature. Some of them, Hard and Soft Acid-Base Principle, Maximum Hardness Principle, Minimum Polarizability Principle and Minimum Electrophilicity Principle. According to HSAB Principle ${ }^{8}$ introduced by Pearson, "Hard acids prefer to coordinate to hard bases and soft acids prefer to coordinate to soft bases." This approach was introduced considering Lewis acid-base reactions. In many issues like explanation of the stability of molecules, the prediction of the directions of chemical reactions, solubility of ionic salts of the chemistry, HSAB Principle is quite successful. It is important to note that the chemical species having low polarizability are intended to mean. Soft molecules are big and strongly polarizable. Especially in transition metal chemistry, the theory provides important facilities to scientists in terms of the explanation of reaction mechanisms and types of the interactions. Maximum Hardness Principle ${ }^{9}$ is a bridge between chemical stability and hardness concepts. Hard molecules have low polarizability and small size. On the other hand, soft molecules are polarizable and have large size.

In the present paper, our aim is to investigate the biological activity of studied complexes and molecules and is to note binding energies between creatine kinase protein and folic acid derivatives.

\section{MATERIAL AND METHODS}

\section{Computational Details}

The molecular docking studies are performed between the complexes studied and the target protein with HEX 8.0.0 and Auto Dock 4.2.6 programs ${ }^{10}$. Density Functional Theory (DFT) is a widely used method in recent times. In this study, the Gaussian $09^{11}$ program has been used for all calculations. the Gauss View5.0.8 program has been used to prepare the input files of the investigated compounds. Geometries of all the studied compounds were fully optimized based on density functional theory (DFT) with B3LYP method by applying the $6-31+\mathrm{G}^{* *}$ basis set with polarization functions on all atoms and diffuse functions on heavy atoms in the gas phase. DFT calculations were performed to evaluate of chemical reactivity with analysis of global descriptors such as chemical hardness, Energy gap $(\Delta$ Egap $=$ HOMOLUMO), electronegativity, chemical potential, proton affinity (PA), electrophilicity, nucleophilicity.

Quantum chemical descriptors such as electronegativity $(\chi)$, chemical hardness $(\eta)$ and chemical potential $(\mu)$ are defined as derivatives with respect to number of electron $(\mathrm{N})$ of the electronic energy (E) at external potential, $v(r)$. The equations given in Conceptual Density Functional Theory for these parameters are ${ }^{12}$.

$$
\begin{aligned}
& \mu=-\chi=\left(\frac{\partial E}{\partial N}\right)_{v(r)} \\
& \eta=\frac{1}{2}\left(\frac{\partial^{2} E}{\partial N^{2}}\right)_{v(r)}=\frac{1}{2}=\left(\frac{\partial \mu}{\partial N}\right)_{v(r)}
\end{aligned}
$$


Using finite differences approximation [13] to Eq.2, Pearson and Parr obtained the following equations depending on electron affinity (A) and ionization energy (I) of chemical species for chemical hardness, electronegativity and chemical potential

$\chi=-\mu=\left(\frac{I+A}{2}\right)$

$\eta=\frac{I-A}{2}$

Softness is defined as the multiplicative inverse of the global hardness and it is mathematically calculated with the help of Eq. (4)

$\sigma=\frac{1}{\eta}$

The electrophilicity index $(\omega)$ introduced by Parr et al. [14] measures the stabilization in energy when the system acquires an additional electronic charge $\Delta \mathrm{N}$ from the environment. The electrophilicity is defined as in Eq. (5).

$\omega=\frac{\mu^{2}}{2 \eta}=\frac{\chi^{2}}{2 \eta}$

The global electrophilicity index is an important chemical reactivity descriptor giving information about electrophilic power of a chemical compounds is associated with its electronegativity and chemical hardness. Nucleophilicity $(\varepsilon)$ is physically the inverse of the electrophilicity as is given in the equation below (Eq (6)).

$\varepsilon=\frac{1}{\omega}$

(6)

\section{RESULTS and DISCUSSION}

\section{Molecular Docking}

CK-BB consists of a homodimer of the CK-B subunit of the same two brain types. BB-CK is a cytoplasmic enzyme in cellular energy homeostasis where certain fractions of the enzyme are bound to cell membranes, ATPases, and various ATPrequiring enzymes in the cell. The 3B6R selected from the protein data bank contains the highresolution structure of $\mathrm{BB}-\mathrm{CK}$. It sets out the molecular basis of the multiple isoform specific properties of $\mathrm{CK}$, particularly with respect to different subcellular localizations and functional interactions with other proteins. This model is the transition state complex of BB-CK, which is similar to one of the arginine kinase (AK). The molecular docking studies are performed between the complexes studied and the target protein with HEX 8.0.0 and Auto Dock 4.2.6 programs. Active binding forms and binding energies with target proteins for folic acid and folic acid metal complexes are given in Figure 1. The molecular structure of folic acid (FA) and its cadmium (CdFA) and mercury (Hg-FA) complexes were optimized at HF-LANL2DZ/6-31G level. The optimized structure of mentioned compounds was given in Figure 2. In Table 1, quantum chemical descriptors are given for studied compounds.

\begin{tabular}{|l|l|l|l|l|l|l|l|l|l|}
\hline Compounds & Eномо & Elumo & Ehomo(eV) & Elumo(eV) & I=Ehomo & A=-ELumo & SE=LUMO-HOM0 & $\eta=(\mathrm{I}-\mathrm{A}) / 2$ & $\sigma=1 / \eta$ \\
\hline FA & $-0,3008$ & 0,0560 & $-8,1844$ & 1,5225 & 8,1844 & $-1,5225$ & 9,7069 & 4,8535 & 0,2060 \\
\hline Cd-FA & $-0,2992$ & 0,0571 & $-8,1417$ & 1,5538 & 8,1417 & $-1,5538$ & 9,6955 & 4,8477 & 0,2063 \\
\hline Hg-FA & $-0,2994$ & 0,0524 & $-8,1482$ & 1,4253 & 8,1482 & $-1,4253$ & 9,5736 & 4,7868 & 0,2089 \\
\hline
\end{tabular}




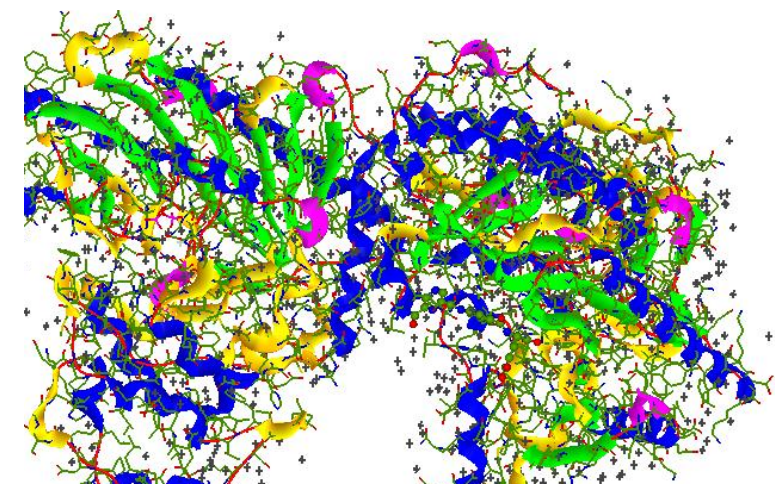

Folic acid with 3B6R Bind. En. $=-363.25 \mathrm{~kJ} / \mathrm{mol}$
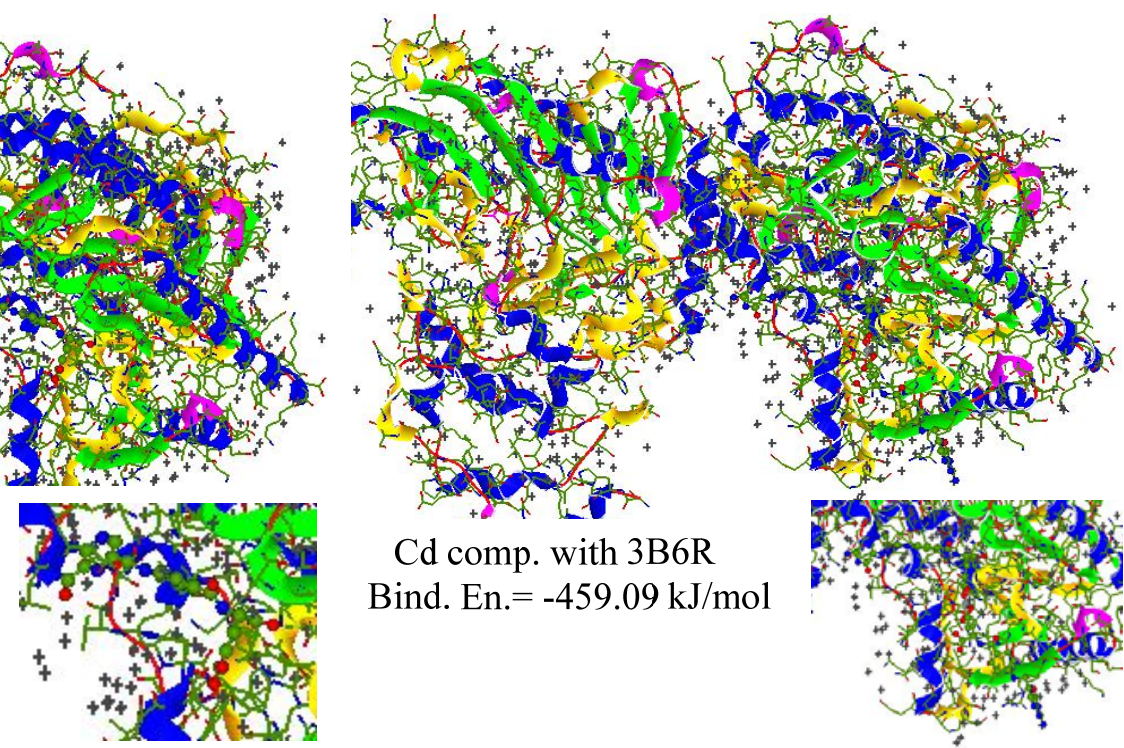

Cd comp. with 3B6R

Bind. En. $=-459.09 \mathrm{~kJ} / \mathrm{mol}$
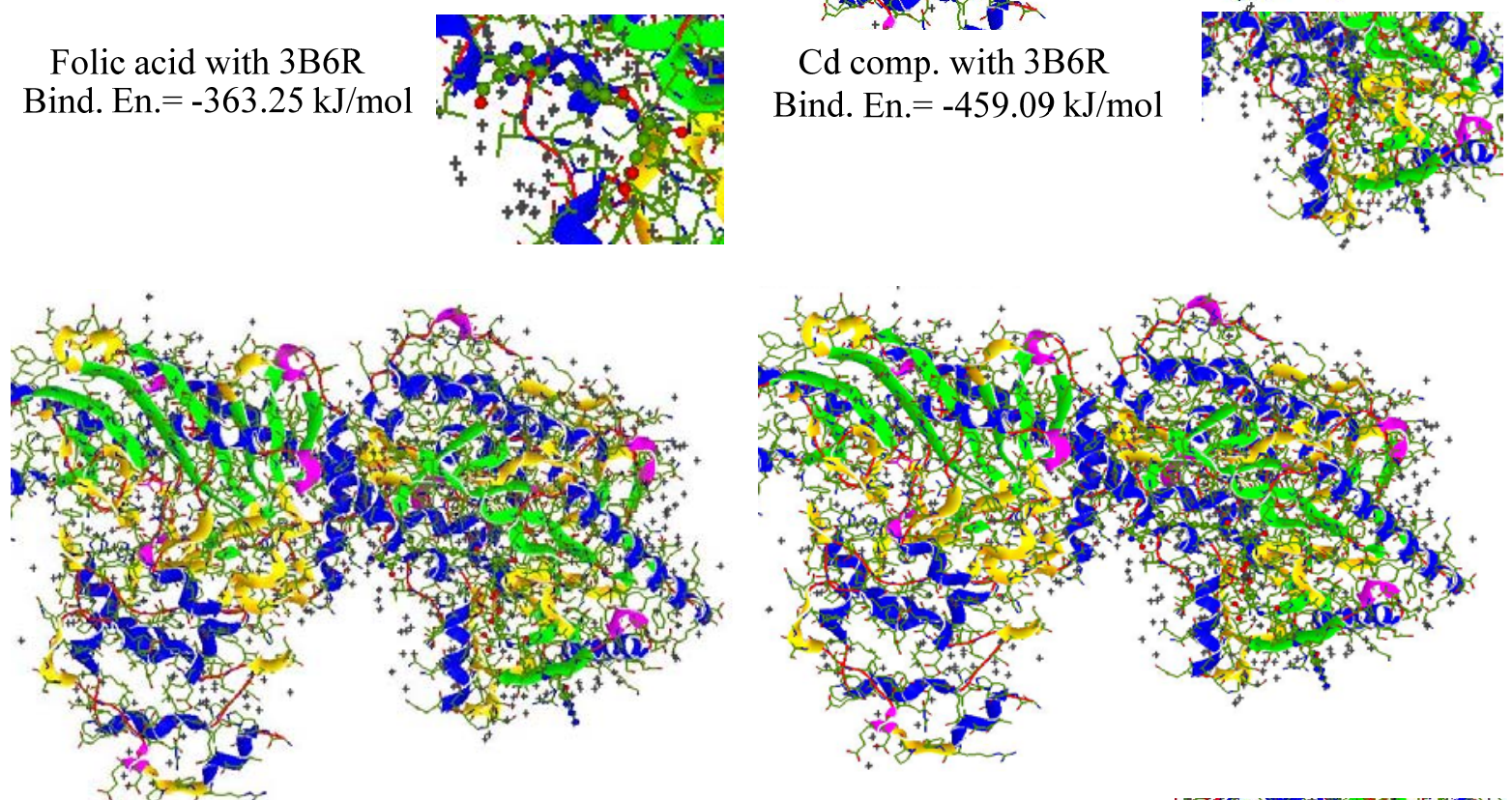

$\mathrm{Cu}$ comp. with 3B6R Bind. En. $=-459.42 \mathrm{~kJ} / \mathrm{mol}$
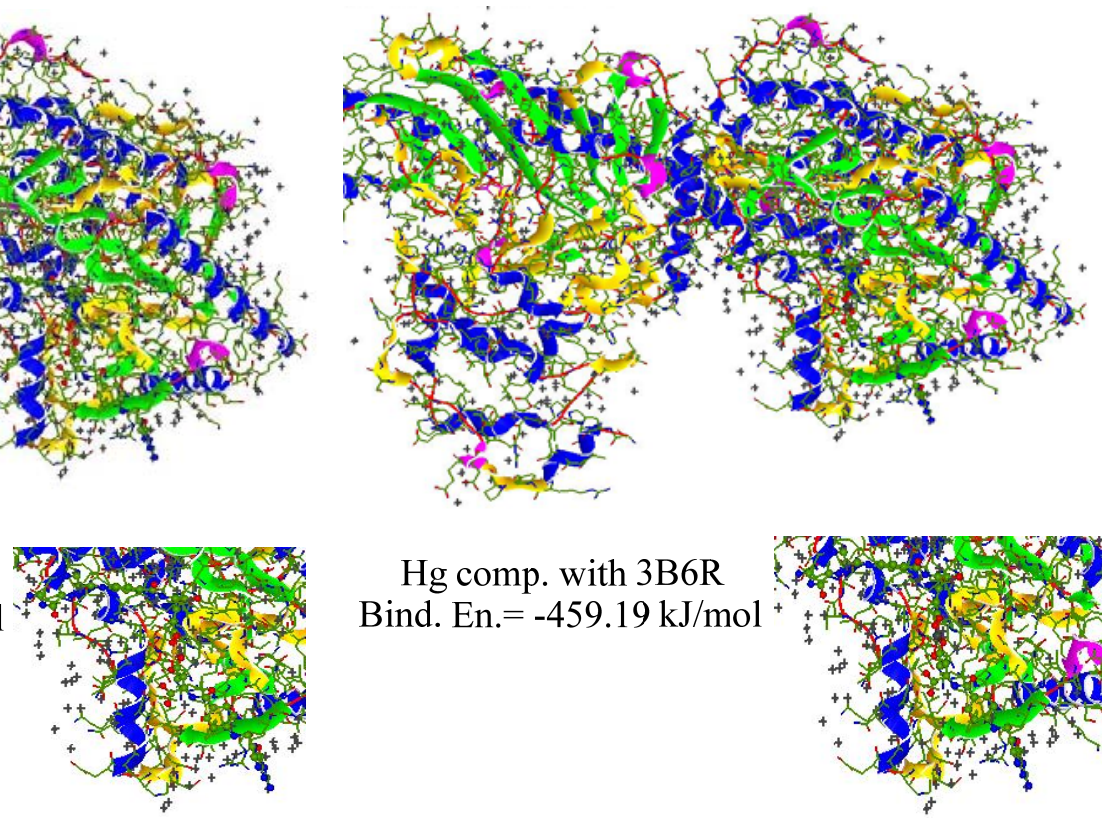

Hg comp. with 3B6R Bind. En. $=-459.19 \mathrm{~kJ} / \mathrm{mol}$

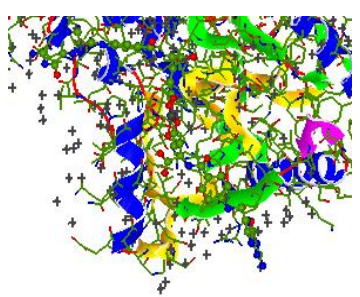

Figure 1: Docking pose and binging energies of folic acid and its metal complexes.

The results obtained by docking folic acid and its derivatives with 3B6R showed that folic acid complexes form H-bonds with the amino acid residue Asp181. Folic acid and their metal complexes inhibit different regions of the target protein, while all complexes are accommodated in almost the same region of the protein. Furthermore, in the copper complex, electrostatic interaction at close distance with Lys196 (2.16 §) and Ala204
$(2.62 \AA)$ may have increased the interaction energy unlike other complexes. In summary, according to the molecular docking results of folic acid and cadmium, copper and mercury complexes; copper complex has more inhibition activity than other complexes. In addition, the metal complexes of folic acid may provide an advantage in increasing the inhibitory activity of folic acid. 

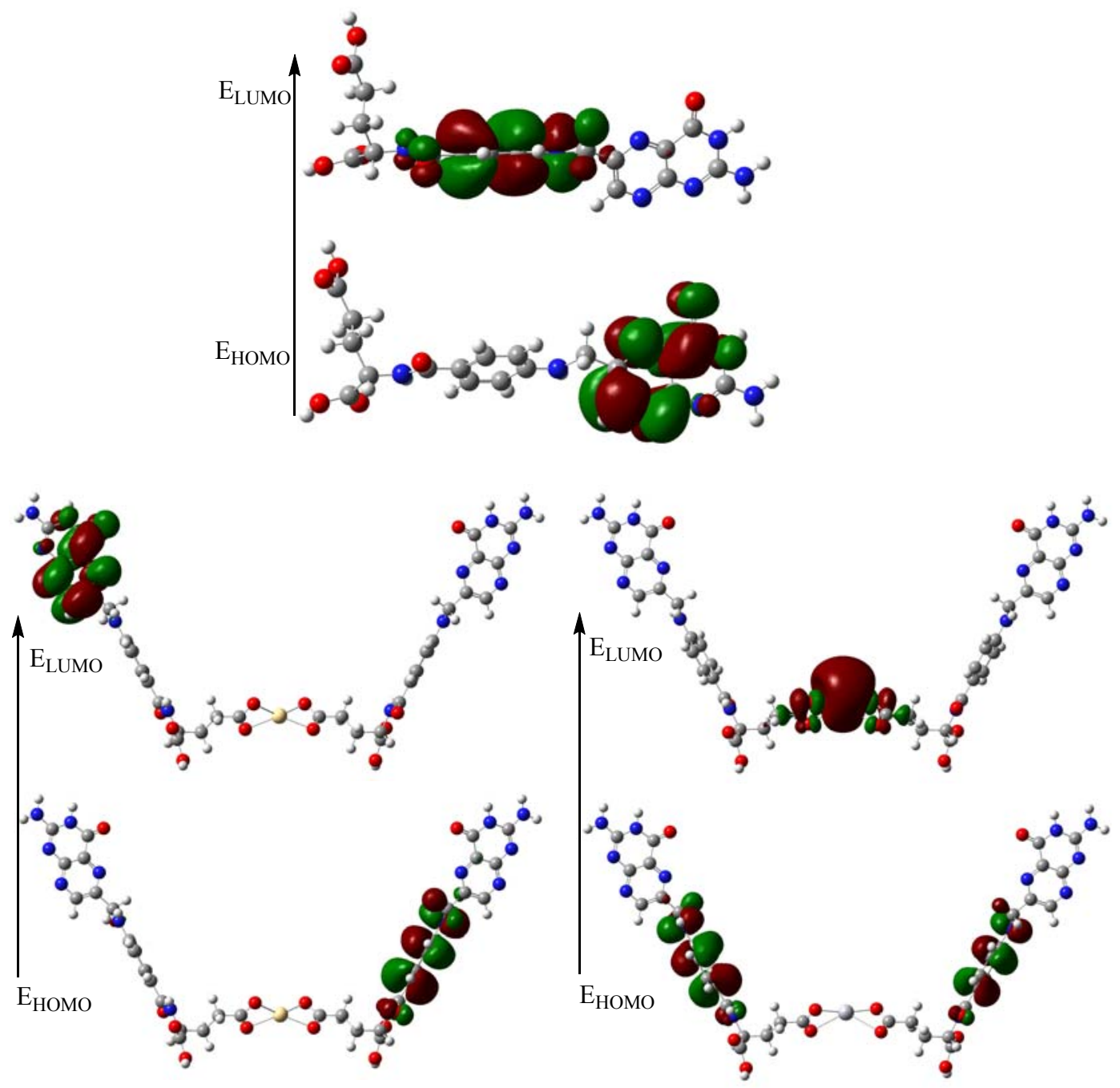

Figure 2: Frontier molecular orbitals (HOMO and LUMO) of FA, Cd-FA and Hg-FA

According to Maximum Hardness Principle, stable molecules are harder compared to reactive ones and chemical hardness is a stability criterion like polarizability. It is apparent from the data $\mathrm{Hg}-\mathrm{Fa}$ is more reactive and its binding energy on studied enzyme are higher compared to others.

\section{CONCLUSION}

Because of the importance of folic acids and its derivatives, in this study, we analyzed the chemical reactivity of folic acid and its derivatives using DFT and Molecular Docking Programmes and investigated the power of the interactions with some well- known target proteins of the aforementioned molecules. In the present work, we analyzed the interactions between folic acid and some important proteins. The results showed that folic acid is strongly binding to studied proteins.

\section{REFERENCES}

1. Selhub, J., \& Rosenberg, I. H. (2016). Excessive folic acid intake and relation to adverse health outcome. Biochimie, 126, 71-78.
2. Huo, Y., Li, J., Qin, X., Huang, Y., Wang, X., Gottesman, R. F., ... \& Fu, J. (2015). Efficacy of folic acid therapy in primary prevention of stroke among adults with hypertension in China: the CSPPT randomized clinical trial. Jama, 313(13), 1325-1335.

3. Gomes, S., Lopes, C., \& Pinto, E. (2016). Folate and folic acid in the periconceptional period: recommendations from official health organizations in thirty-six countries worldwide and WHO. Public health nutrition, 19(1), 176-189.

4. Koch, W., \& Holthausen, M. C. (2015). A chemist's guide to density functional theory. John Wiley \& Sons.

5. Parr, R. G. (1980). Density functional theory of atoms and molecules. In Horizons of Quantum Chemistry (pp. 5-15). Springer, Dordrecht.

6. Chattaraj, P. K., Sarkar, U., \& Roy, D. R. (2007). Electronic structure principles and aromaticity. Journal of chemical education, 84(2), 354. 
7. Chattaraj, P. K., \& Sengupta, S. (1996). Popular electronic structure principles in a dynamical context. The Journal of Physical Chemistry, 100(40), 16126-16130.

8. Pearson, R. G. (1968). Hard and soft acids and bases, HSAB, part 1: Fundamental principles. Journal of Chemical Education, 45(9), 581.

9. Pearson, R. G. (1993). The principle of maximum hardness. Accounts of Chemical Research, 26(5), 250-255.

10. Al-Khayyat, M. Z., \& Al-Dabbagh, A. G. (2015). Homology modeling and docking studies of a plasmid partition protein, ParF: Flavonoids as anti-plasmid agents. Journal of Computational Methods in Molecular Design, 5(3), 25-32.
11. Barone, V., Bloino, J., \& Biczysko, M. (2009). Vibrationally-resolved electronic spectra in GAUSSIAN 09. Revision A, 2, 1-20.

12. Ghosh, D. C., \& Islam, N. (2011). Whether there is a hardness equalization principle analogous to the electronegativity equalization principle-A quest. International Journal of Quantum Chemistry, 111(9), 1961-1969.

13. Geerlings, P., \& De Proft, F. (2008). Conceptual DFT: the chemical relevance of higher response functions. Physical Chemistry Chemical Physics, 10(21), 3028-3042.

14. Chattaraj, P. K., Sarkar, U., \& Roy, D. R. (2006). Electrophilicity index. Chemical reviews, 106(6), 2065-2091. 